\title{
Personal health coach - competence and social-professional role
}

\begin{abstract}
In conditions of civilizational hurry and, at the same time, specialisation and professionalization of almost ever sphere of life, the need of consultancy services is emerging.

The aim of this work is to present a new social phenomenon of the increasing popularity of personal health coaches, who provide consultancy in the field of preventive medicine and health promotion.

The study shows the positive role of personal health coaches in social area and attempts to determine their competence in offered services e.g. organizing, planning and conducting individual health training. The fact of overly narrow understanding of the training of health and the concept of health coach, using only the resources in the area of physical culture, has been noted.
\end{abstract}

Keywords: health coach, health training, health, health promotion.

DOI: $10.12923 / \mathrm{j} .0044-2011 / 123-3 / \mathrm{a} .10$

\section{INTRODUCTION}

Functioning in the age of mass pop culture, we give in to consumptionism in almost every sphere of life. It is increasingly difficult to satisfy constantly growing needs, also in the field of preventive medicine and health promotion. The market of recreation $\&$ health products and services is regularly expanding. In order to live in a healthy way and improve the quality of our lives, we need knowledge and skills in this respect.

Currently the problem of access to knowledge has been almost completely eliminated; there is a more important dilemma relating to the excessive amount of knowledge, the proper selection of information and its practical use. In conditions of civilizational hurry and, at the same time, specialisation and professionalization of almost every sphere of life, the need of consultancy services is emerging. Reserved for and associated only with medical sector specialists until recently, the sphere of health and preventive medicine has become an open and relatively differentiated service market with specialists from very many fields. All of this has emerged in connection with the new holistic social and ecological health paradigm, which is superseding the biomedical model of health and disease.

Preventive medicine and health promotion, according to which health is understood as a biopsychosocial or even spiritual condition of well-being, includes concepts that largely exceed the system of primary or specialist health service [1]. According to contemporary models or factors determining human health, responsibility for them rests on the human being - the creator of his own health, whose task is to fulfil the project of his life in a responsible manner. In contemporary democratic societies, the state is only obliged to provide appropriate conditions that allow an individual to develop independently and to decide about the quality of his life [2].

With regard to popularisation and promotion of health education, much has already been done. Thanks to the omnipresent mass media that integrate the world, pro-health behaviours have been popularised in many developing countries, including Poland. However, the awareness of healthy and unhealthy life and its consequences for general wellbeing is not enough in itself. The popularisation of certain contents is not sufficient for an individual to use it for the fulfilment of his own life strategy.

Actions aimed at elevating the value of health in the general value hierarchy are not sufficient, either. What emerges is an urgent need to model skills relating to the change of lifestyle, practical skills regarding the implementation of desired behaviours, etc. The modelling of skills occurs usually as a part of occasional campaigns, sometimes health promotion programs, but the number of these initiatives and interventions seems to be insufficient. In comparison with countries of Western Europe, we occupy a much worse position in terms of habits related to preventive medicine $[3,4]$.

What is particularly underdeveloped in Poland, are health promotion activities, i.e., impacts aimed at increasing or multiplying the health potential. The belief that healthy persons also need support from specialists providing broadly understood health services is still absent.

The reorientation of the health care system from reparative medicine to preventive medicine is still only a postulate included in the document under the name "National Health 
Program", which is constantly revised [5]. The reparative vision of medicine is still dominant. Doctors engage mainly in the treatment of the sick body and pay less attention to its improvement; they focus on diseases rather than health. Individual healthy lifestyle consultants can fill this niche.

The aim of this work is to present a new social phenomenon of the increasing popularity of personal health coaches, who provide consultancy in the field of preventive medicine and health promotion.

\section{Health coach and the concept of his social-professional role}

Because of the consumptive attitude to reality, the demand for exclusive services is growing also in Poland, including recreation and preventive medicine. A certain type of fashion for individual services is a manifestation of one's own social and material position.

Krawański [6] thinks that the „healthy man's doctor” is a need of modern times and a huge opportunity. Not only sick people, but also those who enjoy good health need support. The people who have ambitions to enjoy the high level of physical fitness and efficiency, which are important measures of human health [7], generate a demand for an individual health coach as a healthy lifestyle consultant [8].

The idea of a personal coach emerged at the end of the 20th century in the United States and other highly developed countries in response to the need to individualise physical activity and take care of one's own health. At first, consultants' services regarding fitness, body appearance and health were used only by wealthy persons, who treated health training as a tool supporting their career [9]. An individual coach is particularly popular among celebrities, for whom their support determines their own status and is a hallmark of professionalization that affects favourably their image.

Coaching, mentoring, consulting or training of various skills are becoming increasingly popular in Poland, too. In numerous guides and mass-circulation publications, mainly American ones, we can read: "You need a coach to make a success", "Everyone needs a coach who will motivate and support us". The typically American philosophy of "man of success" has been implemented quickly and very easily in Europe and other regions of the world [10,11]. It is expressed by the idea that not only a sportsman, artist, manager, entrepreneur, but also everyone can, or even should, make a success, and an individual coach - a consultant and an expert specializing in a given field can help to accomplish this goal.

However, a rich offer of guidebooks is becoming insufficient, as only interactive forms of reaching the customer can succeed in current reality. A new phenomenon and a contemporary trend is the individual management of personal health, happiness and lifestyle with the use of computer programs performing analyses of various data from generally available measurement devices. Training plans, dietary recommendations and other guidelines are designed on the basis of a rich database. New Internet tools constitute an information flow channel. The technologisation of the private way of life and the specific philosophy of conduct determining the place of an individual in the community has become a fact.

Health training is a work-based process. These are praxeological cycles of strictly specified and precise interventions, which are more than just a form of occasional amusement. This self-improvement work in spare time and the precise regulation of one's own lifestyle requires support from a specialist with broad competences.

A personal health coach is a type of specialist life-coaching, i.e. personal development consultancy with regard to human health and life quality [10].

This idea is developing on the wave of the culture of individualism, which is promoted by the mass media as an expression of autonomy and freedom in power over self. However, it is worth noticing not only the favourable side of this phenomenon. The individualism that prompts people to take care of themselves, develop, be healthy and constantly young has also its repressive side. The cult of the body and youth and the desire for success and its symbols turns people into hostages of their own needs, which are sometimes irrational. Internal discipline is a means to shape oneself, one's body and personality according to generally promoted canons of beauty, good and happiness. Many philosophers reflect on the lengths to which the contemporary human being goes for the purpose of self-creation and selfaffirmation by treating his body and health purely instrumentally as a means of fulfilment of needs stimulated by the mass pop culture of consumption [12].

The problem is not new, and the search for the sense of life, happiness and well-being has accompanied people since time immemorial. „As in the case of Puritans cultivating a certain spiritual condition - persistent belief in grace, the lifestyle of the new middle class is guided by the care about experiencing optimism, happiness and youth". In such individualism, the human being and his self becomes an object of inexhaustible work [13]. Being convinced that we live in the society of consumption, many persons try to buy themselves happiness and satisfaction by investing in a professional consultant - a coach who will become responsible for the customer's health and desired appearance.

In developing European countries, we can observe, on the one hand, the awareness and possibility of self-creation and, on the other hand, the lack of competence in this respect. This is why there is a demand for a mentor who will help to fulfil the needs of being healthy, fit and good-looking in the light of prevailing canons of pop culture.

A health coach is needed for fulfilling operational goals in the program of one's own life.

\section{Individual health training}

In the post-modern culture, both anti-health and prohealth behaviours have been popularised. Caring about health becomes necessary in current conditions of the scientific and technological revolution [14]. Fuelled by comfort, civilizational progress has produced passivity, and the needs of physical activity and other similar needs are biologically conditioned. It is commonly known that the low level of fulfilment of natural needs is the reason of many civilizational diseases [15].

Individualism is the key rule in contemporary educational space. In the satisfaction of needs, it determines contemporary health promotion programs and all successful interventions in this respect. An individual and subjective approach to a human being is the essence of the profession of a coach and is decisive for its effectiveness. Individualisation results 
from the complexity and huge differentiation of the human being in terms of genetic, cultural and environmental determinants, including age, sex, needs, current capacities, interests, current and previous lifestyle and many others. Each human is an individual and unique being, so he requires a personalistic approach.

Health behaviours were popularised as a determinant of the quality of life on the wave of the idea of health promotion - a health revolution defined as my health in my hands [16]. The idea of health and the related quality of life has caught on very easily in the commercialised global world. The development of behavioural medicine and the media appeal of the subject of health have created a basis for the development of paramedical services and, consequently, services in the broadly understood field of lifestyle, including mainly physical and health culture.

According to A. Bator and T. Kasperczyk [17], "health training is a kind of physical activity undertaken for health reasons that is aimed at increasing the level of psychophysical fitness and capacity and improving vital processes of the human organism".

It is, therefore, a purposeful systematic use of specific forms of stimuli in the optimum quantity, quality and frequency so that it could stimulate the growth of the human organism for pro-health purposes. The expected result of health training is the maintenance and improvement of health [18]. This engineering approach to spare time is typical of the modern world filled with rationality. It is worth noticing that health training cannot be limited only to physical activity recommendations; this process encompasses various kinds of intervention in all components of healthy lifestyle. Thus, a health coach is a manager of this process. He supports an individual who decides to manage his life in health. It is a comprehensive life process that requires knowledge and experience.

A health coach acts in the field of spare time, but his interventions penetrate into an individual's way of life in the form of orders and prohibitions regulating the method of leisure and work.

\section{Health coach's competences}

Success in the role of a personal health coach depends largely on his ability to create his own image of a competent and trustworthy person and on the authority created by him.

The persons with highest predispositions to this role are graduates of physical education, tourism and recreation or physiotherapy with additional certificates of completion of various courses in the field of recreation and preventive medicine, including dietetics. The more extensive the range of additional supplementary rights, the broader the possibility to have an impact on an individual. Personal aptitudes such as an interesting extrovert personality, authenticity, optimism and broad interests are necessary.

Education should encompass broad preparation in the field of:

- thematic competences - the need to possess knowledge in a number of fields, i.e. health promotion, health education, spare time animation, psychology, health pedagogy, knowledge of human physiology, the theory and methodology of health training, health behaviours, including in particular healthy diet and physical activity;
- creative competences - necessary for adapting flexibly to the customer, making suggestions and mobilising the customer's potential. Creative thinking is necessary for planning goals, processes and effective ways of reaching a solution;

- psychological and pedagogical competences - necessary for educational interventions aimed at introducing necessary changes in lifestyle, e.g., supporting, inspiring and motivating. A relationship based on trust is the basis of effectiveness and a distinguishing quality of a personal coach. It is a specific friend who manages health, a teacher and a guide to the world of health values. He trains others in the independent care of health and shapes an affirmative attitude to life;

- communication competences - verbal, non-verbal, precise, often mobile communication making use of modern data communication solutions;

- technological competences - handling of equipment, e.g. sport and recreation equipment, or training support and work control instruments;

- self-education competences - related to continuous professional development (fast learning skills, self-analysis of personal career achievements, permanent self-development supported by training courses).

It is the free market of recreation and health services that models the professional outline of a personal health coach; unfortunately, he often has too narrow competences. In most cases, he only assumes the role of an instructor - an expert in activities aimed at improvement of the physique. The excessively narrow understanding of a consultant's role (e.g. only in terms of diet and physical activity) does not contribute to the general well-being of a person. He should be a leader managing an individual's life in a holistic way, whose main task is the creation of healthy lifestyle. He is a consultant and a guide to recreational and preventive medicine services who assumes the role of a preventive medicine manager. He should try to develop all components of health-oriented capacity. He must be able to plan, implement and control health behaviours in strict co-operation with the customer.

\section{CONCLUSIONS}

Taking into account global tendencies in health promotion and the globalisation of the market of preventive medicine products and services, a personal coach is a profession of the future. The future of this concept should be sought, among others, in the demographic structure of European societies. Being aware of the role of preventive medicine and health promotion activities, aging societies will give an impulse for the development of the above services in the quality of life.

In Poland personal coach's services are used most often by persons from the age group 30-40 years, who account for $45 \%$ of all customers. These persons want to have the certainty of results of their self-improvement, attach high importance to safety guaranteed by the coach's knowledge and experience and pay attention to comfort, because that releases them from the problems involved in independent planning, the seeking of proper solutions etc. Exercises can 
be adapted to an individual's rhythm of life, which will have a favourable impact on time management.

It can be assumed that theoretically everyone can make use of personal coach's services, but the financial barrier seems to be a strong constraint, even though the cost of services is relatively differentiated and depends on the offer. Individual coaches work most frequently in fitness clubs, wellness centres, spas, holiday resorts and hotels. Because of the form of their activity (employment, place etc.), conditions of their work can be very different.

The problem that is encountered most frequently among persons involved in preventive medicine or health promotion activities is the decreasing level of motivation. A specially prepared program of activities and individual professional care increases motivation to self-improvement, which translates directly into better results. It has been proved that physical exercises with a coach is more intense than individual exercises [19]. Higher intensity is a favourable result of working with a coach.

A personal coach treats each customer individually, selects physical exercises relevant to the customer's age, physical structure, skills, fitness and lifestyle as well as the diet, physical therapy or physique-modelling treatment.

The very fact of bearing costs of investment in training mobilises or even forces the customer to take up systematic work on the implementation of established plans.

In the individual coach-customer relationship, it is possible not only to instruct and teach, but also to change personality towards reinterpretation of health and life values.

The increasing trend of individual services that is developing in the fitness industry can certainly become even stronger due to undoubtedly numerous benefits. Disseminated by means of interactive and global media, these benefits create a fashion for the prospective profession of a personal coach.

\section{REFERENCES}

1. Downie RS, Fyfe C, Tannahill A. Health promotion. Models and Values. New York: Oxford University Press; 1994.

2. Wojtczak A. Zdrowie publiczne wyzwaniem dla systemów zdrowia XXI wieku. Warszawa: PZWL; 2009.

3. Highlights on health in Poland 2005. WHO; 2006.

4. Wojtyniak B, Goryński P. Sytuacja zdrowotna ludności Polski. Warszawa: NIZP, PZH; 2008.

5. Narodowy Program Zdrowia 2007-20015 (2007), Załącznik do Uchwały nr 90/2007 Rady Ministrów z dnia 15 maja 2007r. Warszawa; 2007. p. 15.

6. Krawański A. Nauczyciele wychowania fizycznego w procesie społecznej edukacji prozdrowotnej. Wych Fiz i Zdrow. 1996;2:53-8.

7. Drabik J. Pedagogiczna kontrola pozytywnych mierników zdrowia fizycznego. Gdańsk: AWFiS; 2006.

8. Janicki G. Nowe aspekty czasu wolnego na przełomie wieków. In: Z. Dziubiński, K. W. Jankowski (ed). Kultura fizyczna w społeczeństwie nowoczesnym. Warszawa: AWF; 2009. p. 380-91.

9. Bułdak R, Sawczyn T. Zarządzanie zdrowiem. Wrocław: Szkoła Transfromacji; 2009.

10. Vickers A., Bavister S. Coaching. Gliwice: Wydawnictwo Helion; 2007.

11. Blanchard S, Homan M. Coaching. Poznaj tajniki sukcesu. Gliwice: Wydawnictwo Helion; 2007.

12. Symotiuk S. Stany ducha. Kraków: Instytut Wydawniczy "Maximum"; 2011.

13. Jacyno M. Kultura indywidualizmu. Warszawa; PWN; 2007. p. 10.

14. Nosko J. Zachowania zdrowotne i zdrowie publiczne. Łódź: Instytut Medycyny Pracy; 2005.

15. Heszen I, Sęk H. Psychologia zdrowia. Warszawa: PWN; 2007.

16. Syrek E. Zdrowie i wychowanie a jakość życia. Perspektywy i humanistyczne orientacje poznawcze. Katowice: Wydawnictwo Uniwersytetu Śląskiego; 2008.

17. Bator A, Kasperczyk T. Trening zdrowotny z elementami fizjoterapii. Kraków: AWF; 2000. p. 21.

18. Nowak PF. Rola treningu rekreacyjno-zdrowotnego na tle wzorców zachowań we współczesnej kulturze. In: S. Zagórny (ed). Wzory kultury somatycznej a styl życia. Opole: Politechnika Opolska; 2008. p. 59-70.

19. Ratamess, NA, Faigenbaum AD, Hoffman JR, Kang J. Self-Selected Resistance Training Intensity in Healthy Women: The Influence of a Personal Trainer. J Strength Cond Res. 2008;22(1):103-11.

\author{
Informacje o Autorze \\ Corresponding Author \\ Paweł F. Nowak, \\ WWFiF Politechnika Opolska, \\ ul. Prószkowska 76, 45-758 Opole, \\ tel. 697-719-604 \\ E-mail:p.nowak@po.opole.pl
}

Dr Pawel F. NowaK - adiunkt; Katedra Metodyki Wychowania Fizycznego, Wydział Wychowania Fizycznego i Fizjoterapii, Politechnika Opolska. 